\title{
Efisiensi Penggunaan Cahaya Matahari oleh Tebu pada Berbagai Tingkat Pemupukan Nitrogen dan Fosfor
}

\section{Sugarcane Light Use Efficiency at Various Levels of Nitrogen and Phosphorus Fertilization}

\author{
Wawan Pembengo ${ }^{1 *}$, Handoko ${ }^{2}$, dan Suwarto ${ }^{3}$ \\ ${ }^{1}$ Jurusan Agroteknologi, Fakultas Pertanian, Universitas Negeri Gorontalo \\ (Gorontalo State University), J1 Jend Sudirman No 6 Kota Gorontalo 96128 Propinsi Gorontalo, Indonesia \\ ${ }^{2}$ Departemen Geofisika dan Meteorologi, Fakultas MIPA, Institut Pertanian Bogor \\ (Bogor Agricultural University), J1 Meranti Kampus IPB Darmaga 16680, Indonesia \\ ${ }^{3}$ Departemen Agronomi dan Hortikultura, Fakultas Pertanian, Institut Pertanian Bogor \\ (Bogor Agricultural University), J1. Meranti, Kampus IPB Darmaga, Bogor 16680, Indonesia
}

Diterima 31 Januari 2012/Disetujui 8 Agustus 2012

\begin{abstract}
Light use efficiency is a crucial parameter in plant growth associated with accumulation of energy interception. Nitrogen and phosphorus deficiency reduce leaf area index (LAI) and specific leaf nitrogen and phosphorus (SLN and SLP) content and reduce efficiency of light intercepted by plant canopy structure. This research was conducted in Kebun Bunga Mayang PTPN VII, North Lampung Regency, Lampung Province (0450'S, 104 52 'E, $38 \mathrm{~m}$ above sea level) from July 2008 to September 2009. Treatments were distributed in the field under a randomized complete block design factorial with three replications. The increase in nitrogen fertilizer (N) improved sugarcane light use efficiency. The light use efficiency of the sugarcane plants fertilized with $225 \mathrm{~kg} \mathrm{~N} \mathrm{ha}^{-1}$ was $2.29 \mathrm{~g} \mathrm{MJ}^{-1}$ at maximum stem phase. On the contrary, the increasing of phosphor $(P)$ fertilizer did not affect light use efficiency but increased stem dry matter at maximum seedling phase or about 3 month after planting (3 MAP), at maximum stem phase (9 MAP), and at harvest (11 MAP); total dry matter at seedling phase (5 MAP) and at maximum stem phase (9 MAP). Nitrogen did not interact with $P$ in affecting light use efficiency.
\end{abstract}

Keywords: fertilization $N$ and $P$, interception radiation, light use efficiency, sugarcane

\section{ABSTRAK}

Efisiensi penggunaan cahaya merupakan komponen penentu pada pertumbuhan dan perkembangan tanaman yang dihubungkan dengan produksi akumulasi biomassa dari intersepsi energi. Defisiensi $N$ dan P menurunkan Indeks Luas Daun (ILD), kandungan spesifik $N$ dan P pada daun (SLN dan SLP) tanaman sehingga terjadi proses reduksi intersepsi dan efisiensi penggunaan cahaya oleh struktur tajuk tanaman. Penelitian ini dilaksanakan di Kebun Bunga Mayang PT Perkebunan Nasional VII Kabupaten Lampung Utara, Provinsi Lampung (04050' LS, 104052' BT, 38 m dpl) pada bulan Juli 2008 hingga September 2009. Penelitian disusun berdasarkan rancangan kelompok lengkap teracak dengan 3 ulangan. Peningkatan pemupukan nitrogen (N) meningkatkan nilai efisiensi penggunaan cahaya oleh tanaman tebu. Pemupukan $225 \mathrm{~kg} \mathrm{~N} \mathrm{ha-1}$ menghasilkan nilai efisiensi penggunaan cahaya matahari oleh tanaman tebu pada fase batang maksimum (5-9 BST) yaitu $2.29 \mathrm{~g} \mathrm{MJ}^{-1}$. Peningkatan pemupukan fosfor $(P)$ tidak meningkatkan nilai efisiensi penggunaan cahaya tanaman tebu namun meningkatkan pada bobot kering batang tebu pada fase anakan maksimum (3 BST), batang maksimum (9 BST) dan panen (11 BST); bobot kering total tebu fase anakan tetap (5 BST) dan batang maksimum (9 BST). Pemupukan N tidak berinteraksi dengan P dalam meningkatkan nilai efisiensi penggunaan cahaya tanaman tebu.

Kata kunci: efisiensi penggunaan cahaya, intersepsi radiasi, pemupukan $N$ dan $P$, tebu

\section{PENDAHULUAN}

Efisiensi penggunaan cahaya merupakan komponen penentu pada pertumbuhan dan perkembangan tanaman yang dihubungkan dengan produksi dan akumulasi biomassa dari intersepsi energi. Salvagiotti dan Miralles (2008)

\footnotetext{
* Penulis untuk korespondensi. e-mail: wawanpembengo@yahoo. com
}

mengemukakan bahwa produksi tanaman ditentukan oleh partisi dan akumulasi biomassa tanaman. Proses tersebut tergantung pada peran kanopi (tajuk) dalam intersepsi PAR (photosynthetically active radiation) yang dipengaruhi oleh indeks luas daun (ILD) dan struktur kanopi serta proses konversi radiasi menjadi akumulasi biomassa tanaman.

Pada tanaman tebu, akumulasi produksi biomassa dipengaruhi oleh intersepsi cahaya oleh tajuk tanaman. 
Nilai intersepsi berbeda untuk masing-masing tahapan perkembangan tanaman tebu karena dipengaruhi oleh beberapa faktor diantaranya indeks luas daun (ILD) dan koefisien pemadaman (extinction coefficient) (Muchow et al., 1994). Defisiensi nitrogen (N) dan fosfor (P) menurunkan indeks luas daun (ILD), kandungan spesifik $\mathrm{N}$ dan P pada daun (SLN dan SLP) tanaman sehingga terjadi proses reduksi intersepsi dan efisiensi penggunaan cahaya oleh struktur tajuk tanaman (Caviglia dan Sadras, 2001; Allison dan Pammentor, 2002; Fletcher et al., 2008).

Modernisasiproduksitanamanpertanianmembutuhkan eksplorasi metode berupa model tanaman guna peningkatan produksi ideal berupa aplikasi metode efisiensi hara, cahaya dan air (Lecoeur dan Ney, 2003; Awal et al., 2006). Manfaat dasar evaluasi pemupukan adalah menyediakan informasi status hara dan prediksi terhadap respon peningkatan hara tersebut (Susila et al., 2010). Berdasarkan pemahaman di atas maka diperlukan kajian dan analisis untuk lebih mengetahui efisiensi penggunaan cahaya matahari oleh tanaman tebu pada berbagai tingkat aplikasi pemupukan $\mathrm{N}$ dan P tertentu.

\section{BAHAN DAN METODE}

Penelitian ini dilaksanakan di Kebun Bunga Mayang, PT. Perkebunan Nasional VII, Kabupaten Lampung Utara, Provinsi Lampung dengan letak lintang 04 $50^{\circ}$ ' LS dan bujur $104^{0} 52^{\prime}$ BT dengan ketinggian tempat $38 \mathrm{~m}$ dpl. Percobaan lapang berlangsung pada bulan Juli 2008 sampai dengan September 2009. Penanaman tebu varietas Kidang Kencana dimulai 20 Agustus 2008 dan panen 8-10 September 2009. Penelitian ini menggunakan rancangan percobaan faktorial rancangan kelompok lengkap teracak (RKLT) dengan tiga ulangan. Faktor pertama berupa pemupukan nitrogen $(\mathrm{N})$ dengan dosis $\left(\mathrm{kg} \mathrm{ha}^{-1}\right)$ 90, 135, 180, $225 \mathrm{~N}$. Faktor kedua adalah pemupukan fosfor $(\mathrm{P})$ dengan dosis $\left(\mathrm{kg} \mathrm{ha}^{-1}\right) 36$, 72, 108, 144 P. Ukuran tiap petak percobaan adalah $15 \mathrm{~m}$ x 10 m. Pengamatan dilakukan pada 3, 5, 9 dan 11 bulan setelah tanam (BST). Peubah pertumbuhan tanaman tebu yang diukur meliputi bobot kering daun, batang, dan akar tanaman tebu, luas daun spesifik (spesific leaf area $=S L A$ ), indeks luas daun (ILD) dan efisiensi penggunaan cahaya matahari tanaman tebu. Data dianalisis dengan menggunakan analisis ragam dan uji lanjut dilakukan menggunakan Duncan Multiple Range Test pada taraf $\alpha=5 \%$. Tahapan fase perkembangan tanaman tebu dinyatakan dengan bulan setelah tanam (BST). Data iklim selama 2 tahun (2008-2009) diamati dengan mencatat curah hujan $(\mathrm{CH})$ menggunakan pengukur curah hujan tipe observatorium, dan suhu di lokasi penelitian. Contoh tanah diambil menggunakan bor Belgi dan ring sampler, serta dianalisis di Laboratorium Balai Penelitian Tanah, Bogor.

\section{HASIL DAN PEMBAHASAN}

\section{Keadaan Agroklimat Wilayah Penelitian}

Hasil analisis tanah pada awal penelitian menunjukkan bahwa tanah pada lokasi penelitian tergolong agak masam dengan $\mathrm{pH}$ 5.6. Kemasaman tanah seperti ini masih optimum untuk pertumbuhan tebu. Menurut Sundara (1998) tebu toleran pada kisaran $\mathrm{pH}$ 5-8.5. Kandungan N-total, Na dan KTK dalam tanah tergolong sangat rendah. Kandungan $\mathrm{Ca}, \mathrm{Mg}$, dan $\mathrm{K}$ tergolong rendah sedangkan kandungan $\mathrm{P}$ tergolong sangat tinggi. Tanah di lokasi percobaan memiliki bobot jenis (bulk density) yang berbeda antara tanah di lapisan atas $(0-20 \mathrm{~cm})$ dan di lapisan bawah $(20-40 \mathrm{~cm})$, masingmasing $1.41 \mathrm{~g} \mathrm{~cm}^{-3}$ dan $1.47 \mathrm{~g} \mathrm{~cm}^{-3}$. Perbedaan bobot jenis ini sangat dimungkinkan karena tanah di lapisan atas lebih banyak bahan organik dibandingkan tanah di lapisan bawah. Porositas tanah yang lebih tinggi pada tanah di lapisan atas (40.40\%) dari pada tanah di lapisan bawah (38.33\%) juga merupakan indikasi tanah di lapisan atas lebih gembur dan mengandung bahan organik lebih banyak.

Curah hujan dari bulan Juli 2008 hingga bulan Agustus 2009 sebesar $1280 \mathrm{~mm}$ per tahun (Gambar 1). Menurut

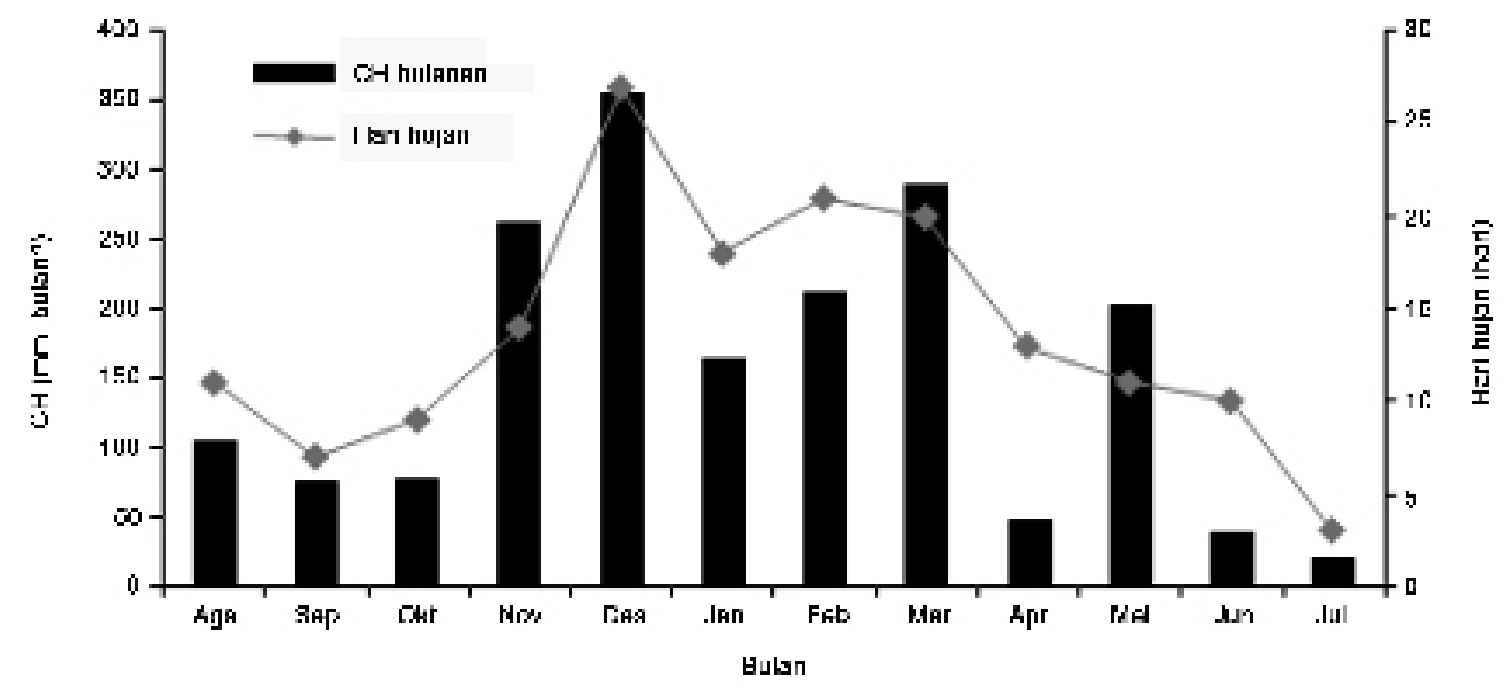

Gambar 1. Curah hujan dan hari hujan selama percobaan lapang 
Sundara (1998) tebu dapat beradaptasi baik pada curah hujan rata-rata $1,800 \mathrm{~mm}_{\text {tahun }}{ }^{-1}$. Lokasi penelitian berdasarkan klasifikasi Schmidth-Fergusson memiliki 9 bulan basah $\left(\mathrm{CH}\right.$ bulanan $\left.\geq 50 \mathrm{~mm}^{\text {bulan }}{ }^{-1}\right)$ dan 3 bulan kering $(\mathrm{CH}$ bulanan $\leq 50 \mathrm{~mm}^{\text {bulan }}{ }^{-1}$ ). Kondisi suhu rata-rata selama penelitian adalah $27{ }^{\circ} \mathrm{C}$, dengan rata-rata suhu maksimum $33{ }^{\circ} \mathrm{C}$ dan rata-rata suhu minimum $23{ }^{\circ} \mathrm{C}$ (Gambar 2). Menurut Sundara (1998) pertumbuhan optimum tebu dicapai pada kisaran suhu $24-30{ }^{\circ} \mathrm{C}$ dan jika dibandingkan dengan kondisi penelitian Martine et al. (1999), maka secara umum kondisi lingkungan pada penelitian ini sesuai untuk pertumbuhan tebu. Radiasi matahari diduga dari data lama penyinaran yang dicatat oleh Stasiun Geofisika Kotabumi, Badan Meteorologi, Klimatologi dan Geofisika (BMKG). Lama penyinaran tertinggi selama bulan April karena di

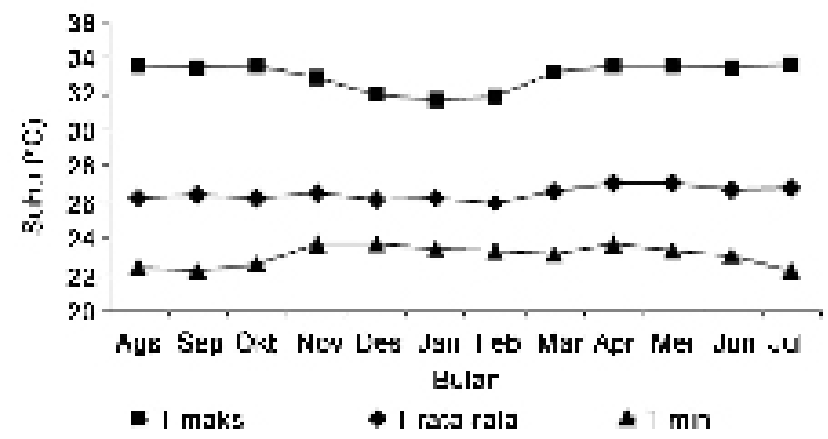

Gambar 2. Suhu bulanan selama percobaan lapang

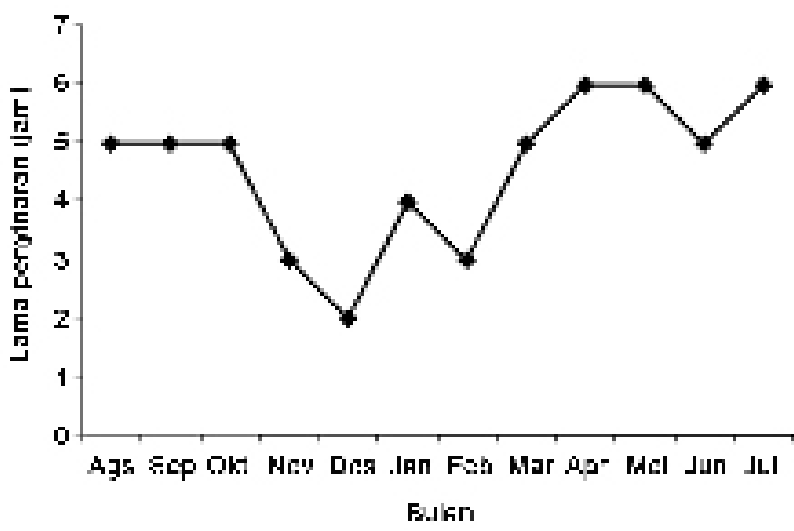

Gambar 3. Lama penyinaran selama percobaan lapang bulan April sudah memasuki musim kemarau dan terendah di bulan Desember, yang merupakan bulan dengan curah hujan tertinggi (Gambar 3).

\section{Intersepsi Radiasi $\left(Q_{\text {int }}\right)$ Tebu}

Nilai intersepsi radiasi $\left(Q_{\text {int }}\right)$ tebu berkisar 7.54 $\mathrm{MJ} \mathrm{m^{-2 }}$ hingga $15.58 \mathrm{MJ} \mathrm{m}^{-2}$. Nilai minimum dicapai pada fase anakan maksimum (1-3 BST) dan maksimum pada fase batang maksimum (5-9 BST). Berdasarkan hasil analisis ragam, $\mathrm{Q}_{\text {int }}$ saat fase anakan maksimum (1-3 BST) dipengaruhi secara nyata oleh pemupukan $\mathrm{N}$ dan $\mathrm{P}$, tapi tidak dipengaruhi secara nyata oleh interaksi pemupukan $\mathrm{N}$ dan $\mathrm{P}$. Pada fase anakan tetap (3-5 BST), fase batang maksimum (59 BST) dan fase panen (9-11 BST) tidak dipengaruhi secara nyata oleh perlakuan pemupukan $\mathrm{N}, \mathrm{P}$ dan interaksinya. Inman-Bamber (1994) menyatakan bahwa fraksi intersepsi mengalami peningkatan yang signifikan di awal fase perkembangan tebu dan kemudian terjadi pelambatan dan penurunan fraksi intersepsi karena perkembangan struktur tajuk serta di akhir fase perkembangan tebu mulai terjadi reduksi ILD. Muchow et al. (1997) mengemukakan bahwa peningkatan laju jumlah trash (death leaf rate) tebu di akhir perkembangan tanaman berdampak pada penurunan laju fraksi intersepsi.

Saat fase anakan maksimum (1-3 BST), perlakuan $225 \mathrm{~kg} \mathrm{~N}$ ha $^{-1}$ menghasilkan intersepsi radiasi $\left(\mathrm{Q}_{\mathrm{int}}\right)$ tertinggi sebesar $9.53 \mathrm{MJ} \mathrm{m}^{-2}$ dibanding dengan perlakuan pemupukan N lainnya (Tabel 1). Peningkatan indeks luas daun (ILD) tebu yang maksimum sebesar 2.82 pada perlakuan $225 \mathrm{~kg} \mathrm{~N} \mathrm{ha}^{-1}$ (Tabel 2) diduga meningkatkan $\mathrm{Q}_{\text {int }}$ tebu pada perlakuan tersebut. Wiedenfeld dan Enciso (2008) mengemukakan bahwa aplikasi pemupukan $180 \mathrm{~kg} \mathrm{~N}^{-1}$ berpengaruh signifikan terhadap peningkatan biomassa tebu berupa struktur tajuk (batang dan daun). Allison dan Pammentor (2002) menyatakan bahwa tanaman tebu yang kekurangan $\mathrm{N}$ di awal perkembangannya akan mempunyai gejala daun berwarna kuning, terjadi reduksi ILD, daun cepat mati atau mengering maka akan mempengaruhi fluktuasi intersepsi radiasi $\left(\mathrm{Q}_{\text {int }}\right)$.

Saat fase anakan maksimum (1-3 BST) perlakuan 144 $\mathrm{kg} \mathrm{P} \mathrm{ha}^{-1}$ menghasilkan intersepsi radiasi $\left(\mathrm{Q}_{\text {int }}\right)$ maksimum sebesar $8.97 \mathrm{MJ} \mathrm{m}^{-2}$ yang nyata lebih tinggi dibandingkan perlakuan pemupukan $\mathrm{P}$ lainnya (Tabel 1). Hal ini

Tabel 1. Intersepsi radiasi $\left(\mathrm{Q}_{\text {int }}\right)\left(\mathrm{MJm}^{-2} \mathrm{hari}^{-1}\right)$ tanaman tebu pada tingkat pemupukan $\mathrm{N}$ dan $\mathrm{P}$ saat fase anakan maksimum (1-3 BST)

\begin{tabular}{lccc}
\hline Dosis N $\left(\mathrm{kg} \mathrm{ha}^{-1}\right)$ & $\left(\mathrm{Q}_{\text {int }}\left(\mathrm{MJm}^{-2}\right.\right.$ hari $\left.^{-1}\right)$ & Dosis P $\left(\mathrm{kg} \mathrm{P} \mathrm{ha}^{-1}\right)$ & $\begin{array}{c}\left(\mathrm{Q}_{\text {int }}\right)\left(\mathrm{MJm}^{-2} \mathrm{hari}^{-1}\right) \\
\left(1-3 \mathrm{BST}^{2}\right)\end{array}$ \\
\hline 90 & $7.93 \mathrm{~d} T)$ & 36 & $8.50 \mathrm{~b}$ \\
135 & $8.44 \mathrm{c}$ & 72 & $8.70 \mathrm{ab}$ \\
180 & $9.03 \mathrm{~b}$ & 108 & $8.76 \mathrm{ab}$ \\
225 & $9.53 \mathrm{a}$ & 144 & $8.97 \mathrm{a}$ \\
\hline
\end{tabular}

Keterangan: Angka-angka yang diikuti oleh huruf yang sama pada kolom yang sama menunjukkan tidak berbeda nyata berdasarkan uji DMRT pada taraf $\alpha=5 \%$ 
Tabel 2. Indeks luas daun (ILD) tanaman tebu pada tingkat pemupukan $\mathrm{N}$ dan $\mathrm{P}$ pada fase anakan maksimum

\begin{tabular}{|c|c|c|c|c|}
\hline \multirow{2}{*}{ Dosis N (kg N ha-1) } & \multicolumn{4}{|c|}{ Dosis $\mathrm{P}\left(\mathrm{kg} \mathrm{P} \mathrm{ha}^{-1}\right)$} \\
\hline & 36 & 72 & 108 & 144 \\
\hline & \multicolumn{4}{|c|}{ Indeks luas daun (ILD) pada fase anakan maksimum (1-3 BST) } \\
\hline 90 & 1.98 & 2.03 & 2.01 & 2.11 \\
\hline 135 & 2.05 & 2.22 & 2.33 & 2.39 \\
\hline 180 & 2.41 & 2.48 & 2.50 & 2.61 \\
\hline 225 & 2.67 & 2.72 & 2.74 & 2.82 \\
\hline
\end{tabular}

disebabkan karena ILD maksimum sebesar 2.82 dicapai pada dosis pupuk P tersebut (Tabel 2). Glaz et al. (2000) dan Prabawa (2006) mengemukakan bahwa pemupukan $\mathrm{P}$ dengan kisaran dosis tertentu yang terlambat akan mengakibatkan tanaman kerdil dan anakan berkurang.

\section{Efisiensi Penggunaan Cahaya Matahari oleh Tebu}

Berdasarkan hasil analisis ragam, efisiensi penggunaan cahaya matahari oleh tebu pada fase batang maksimum (5-9 BST) dipengaruhi secara nyata oleh aplikasi pemupukan $\mathrm{N}$, tapi tidak dipengaruhi secara nyata oleh pemupukan $\mathrm{P}$ dan interaksinya. Pemupukan $\mathrm{N}$ pada fase batang maksimum (59 BST) berpengaruh nyata terhadap efisiensi penggunaan cahaya matahari karena pengaruh $\mathrm{N}$ memicu pertumbuhan tebu, terutama bagian tajuk, dan hal ini berdampak pada peningkatan fraksi cahaya matahari yang diintersepsi oleh tebu. Muchow et al. (1994) menyatakan bahwa peningkatan fluktuasi efisiensi penggunaan cahaya matahari dipengaruhi oleh insiden radiasi yang diintersepsi oleh tajuk tebu yang telah mengalami perkembangan optimal (maksimum).

Nilai efisiensi penggunaan cahaya matahari oleh tebu merupakan slope hubungan perubahan bobot kering total dengan intersepsi radiasi $\left(\mathrm{Q}_{\text {int }}\right)$ tebu. Slope liniear merupakan basis penentuan (estimasi) nilai efisiensi penggunaan cahaya tebu (Inman-Bamber, 1994; Muchow et al., 1994; Martine et al., 1999). Efisiensi maksimum penggunaan cahaya matahari oleh tebu dicapai pada perlakuan $225 \mathrm{~kg} \mathrm{~N} \mathrm{ha}^{-1}$ dengan nilai sebesar $2.29 \mathrm{~g} \mathrm{MJ}^{-1}$ (Tabel 3). Pada perlakuan $225 \mathrm{~kg} \mathrm{~N}^{-}$ ${ }^{1}$ terjadi peningkatan bobot kering total tertinggi sebesar $60.97 \mathrm{~g} \mathrm{~m}^{-2}$ (Tabel 4). Martine et al. (1999) menunjukkan bahwa aplikasi pemupukan $222 \mathrm{~kg} \mathrm{~N} \mathrm{ha}^{-1}, 70 \mathrm{~kg} \mathrm{P} \mathrm{ha}^{-1}$ dan $270 \mathrm{~kg} \mathrm{~K} \mathrm{ha}^{-1}$ dapat memacu peningkatan perubahan bobot kering total tebu sebesar $80 \mathrm{~g} \mathrm{~m}^{-2}$ dan berpengaruh langsung pada fluktuasi efisiensi pengunaan cahaya tebu sebesar $2.38 \mathrm{~g} \mathrm{MJ}^{-1}$ hingga $3.55 \mathrm{~g} \mathrm{MJ}^{-1}$. Hubungan antara efisiensi

Tabel 3. Efisiensi penggunaan cahaya matahari oleh tanaman tebu $\left(\mathrm{g} \mathrm{MJ}^{-1}\right)$ pada tingkat pemupukan $\mathrm{N}$ dan $\mathrm{P}$ pada fase batang maksimum (5-9 BST)

\begin{tabular}{|c|c|c|c|c|}
\hline \multirow{2}{*}{ Dosis N (kg N ha-1) } & \multicolumn{4}{|c|}{ Dosis $\mathrm{P}\left(\mathrm{kg} \mathrm{P} \mathrm{ha}^{-1}\right)$} \\
\hline & 36 & 72 & 108 & 144 \\
\hline & \multicolumn{4}{|c|}{ Efisiensi penggunaan cahaya $\left(\mathrm{g} \mathrm{MJ}^{-1}\right)$ pada fase batang maksimum $(5-9 \mathrm{BST}) \ldots \ldots \ldots \ldots$} \\
\hline 90 & $1.5025 x+37.2$ & $1.4498 x+38.5$ & $1.5134 \mathrm{x}+37.8$ & $1.556 \mathrm{x}+37 . .2$ \\
\hline 135 & $1.5022 x+37.9$ & $1.5605 x+36.9$ & $1.5536 x+36.9$ & $1.6252 x+35.7$ \\
\hline 180 & $1.7252 x+34.2$ & $1.7032 x+34.5$ & $1.7219 x+34.2$ & $1.7479 x+33.9$ \\
\hline 225 & $2.1063 x+28.3$ & $2.1751 x+30.3$ & $2.1109 x+31.0$ & $2.2953 x+28.3$ \\
\hline
\end{tabular}

Tabel 4. Bobot kering total tebu $\left(\mathrm{g} \mathrm{m}^{-2}\right)$ pada tingkat pemupukan $\mathrm{N}$ saat fase batang maksimum

\begin{tabular}{lc}
\hline $\begin{array}{l}\text { Dosis N } \\
\left(\mathrm{kg} \mathrm{N} \mathrm{ha}^{-1}\right)\end{array}$ & $\begin{array}{c}\text { Bobot kering total }\left(\mathrm{g} \mathrm{m}^{-2}\right) \text { pada } \\
\text { tingkat pemupukan } \mathrm{N}\end{array}$ \\
\hline 90 & $57.83 \mathrm{a}$ \\
135 & $58.46 \mathrm{~b}$ \\
180 & $59.89 \mathrm{c}$ \\
225 & $60.97 \mathrm{~d}$ \\
\hline
\end{tabular}

Keterangan: Angka-angka yang diikuti oleh huruf yang sama pada kolom yang sama menunjukkan tidak berbeda nyata berdasarkan uji DMRT pada taraf $\alpha=5 \%$

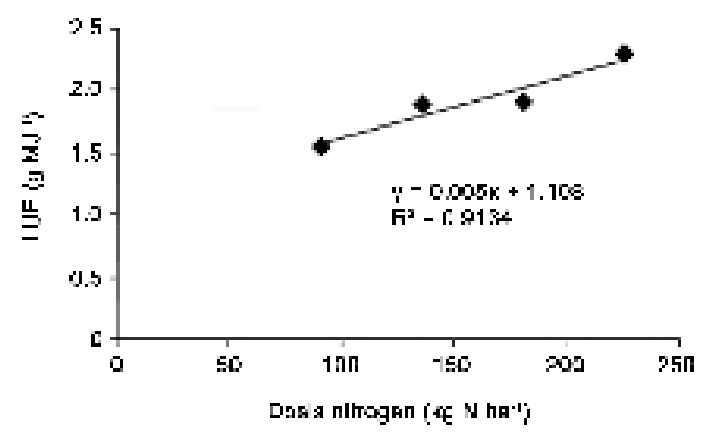

Gambar 4. Efisiensi penggunaan cahaya matahari oleh tanaman tebu pada tingkat pemupukan $\mathrm{N}$ saat fase batang maksimum (5-9 BST) 
penggunaan cahaya matahari oleh tebu dengan pemupukan $\mathrm{N}$ dinyatakan dengan persamaan regresi $\mathrm{y}=0.005 \mathrm{x}+1.108$ dengan koefisien determinasi $\mathrm{R}^{2}=0.913$ (Gambar 4). Peningkatan pemupukan $\mathrm{N}$ memicu peningkatan efisiensi penggunaan cahaya matahari oleh tebu. Perlakuan $225 \mathrm{~kg}$ $\mathrm{N} \mathrm{ha}^{-1}$ menghasilkan efisiensi penggunaan cahaya matahari paling maksimum dibanding dengan perlakuan lainnya.

\section{Bobot Kering Batang Tebu}

Berdasarkan hasil analisis ragam, bobot kering batang tebu pada fase muncul lapang (1 BST) dan fase anakan tetap (5 BST) dipengaruhi secara nyata oleh pemupukan N, $\mathrm{P}$ dan interaksinya (Tabel 5). Kombinasi pemupukan $\mathrm{N}$ dan $\mathrm{P}$ di fase awal perkembangan tebu sangat berkontribusi pada peningkatan bobot kering batang (stalks) tebu (Salgado et al., 2002; Prabawa, 2006). Bobot kering batang tebu saat fase muncul lapang (0-1 BST) pada kombinasi perlakuan $225 \mathrm{~kg} \mathrm{~N}^{-1}$ dan $144 \mathrm{~kg} \mathrm{P} \mathrm{ha}^{-1}, 225 \mathrm{~kg} \mathrm{~N} \mathrm{ha}^{-1}$ dan $108 \mathrm{~kg}$ $\mathrm{P} \mathrm{ha}^{-1}, 225 \mathrm{~kg} \mathrm{~N}^{-1}$ dan $72 \mathrm{~kg} \mathrm{P} \mathrm{ha}{ }^{-1}, 225 \mathrm{~kg} \mathrm{~N} \mathrm{ha}^{-1}$ dan 36 $\mathrm{kg} \mathrm{P} \mathrm{ha}^{-1}$ lebih tinggi jika dibandingkan dengan pengaruh kombinasi perlakuan lainnya. Saat fase anakan tetap (5 BST), bobot kering batang tebu pada kombinasi perlakuan $225 \mathrm{~kg}$ $\mathrm{N}^{-1}$ dengan $144 \mathrm{~kg} \mathrm{P} \mathrm{ha}^{-1}$ lebih tinggi jika dibandingkan dengan perlakuan lainnya (Tabel 5). Hal ini karena pada fase awal perkembangan tanaman tebu tersebut pemupukan $\mathrm{N}$ dan $\mathrm{P}$ sangat berperan dalam perkembangan tanaman tebu tersebut.

Berdasarkan hasil analisis ragam, bobot kering batang tebu fase anakan maksimum (1-3 BST), fase batang maksimum (5-9 BST) dan fase panen (9-11 BST) dipengaruhi secara nyata oleh aplikasi pemupukan $\mathrm{N}$ dan $\mathrm{P}$ sedangkan interaksinya tidak berbeda nyata (Tabel 6, Tabel 7). Wiedenfeld dan Enciso (2008) mengemukakan bahwa aplikasi $180 \mathrm{~kg} \mathrm{~N}^{-1}$ yang dikombinasikan dengan perlakuan irigasi tetes (drip irrigation) menghasilkan peningkatan hasil gula (cane) yang signifikan di daerah sem iarid. Singh dan Mohan (1994) mengemukakan bahwa pada aplikasi pemupukan $200 \mathrm{~kg} \mathrm{~N} \mathrm{ha}^{-1}$ meningkatkan hasil stalk (batang) tebu, namun mulai terjadi penurunan hasil pada aplikasi $300 \mathrm{~kg} \mathrm{~N} \mathrm{ha}^{-1}$. Allison dan Pammentor (2002) mengemukakan bahwa peran $\mathrm{N}$ dalam menentukan produksi gula sangat unik, karena di satu sisi dapat meningkatkan pertumbuhan sehingga akan meningkatkan produksi tebu,

Tabel 5. Bobot kering batang tebu $\left(\mathrm{g} \mathrm{m}^{-2}\right)$ dengan kombinasi perlakuan $\mathrm{N}$ dan $\mathrm{P}$ saat fase muncul lapang (1 BST) dan fase anakan tetap (5 BST)

\begin{tabular}{|c|c|c|c|c|}
\hline \multirow{2}{*}{ Dosis $\mathrm{N}\left(\mathrm{kg} \mathrm{N} \mathrm{ha}^{-1}\right)$} & \multicolumn{4}{|c|}{ Dosis $\mathrm{P}\left(\mathrm{kg} \mathrm{P} \mathrm{ha}^{-1}\right)$} \\
\hline & 36 & 72 & 108 & 144 \\
\hline & \multicolumn{4}{|c|}{ Bobot kering batang tebu $\left(\mathrm{g} \mathrm{m}^{-2}\right)$ pada $1 \mathrm{BST}$. } \\
\hline 90 & $0.57 b$ & $0.56 b$ & $0.56 b$ & $0.56 \mathrm{~b}$ \\
\hline 135 & $0.50 \mathrm{a}$ & $0.57 b$ & $0.63 \mathrm{c}$ & $0.63 \mathrm{c}$ \\
\hline 180 & $0.63 \mathrm{c}$ & $0.69 \mathrm{~d}$ & $0.69 \mathrm{~d}$ & $0.69 \mathrm{~d}$ \\
\hline \multirow[t]{2}{*}{225} & $0.74 \mathrm{e}$ & $0.75 \mathrm{e}$ & $0.74 \mathrm{e}$ & $0.74 \mathrm{e}$ \\
\hline & \multicolumn{4}{|c|}{ Bobot kering batang tebu $\left(\mathrm{g} \mathrm{m}^{-2}\right)$ pada 5 BST.. } \\
\hline 90 & $31.00 \mathrm{a}$ & $31.12 \mathrm{a}$ & $30.99 a$ & $30.96 \mathrm{a}$ \\
\hline 135 & $31.06 \mathrm{a}$ & $31.31 \mathrm{a}$ & $32.09 \mathrm{~b}$ & $32.30 \mathrm{~b}$ \\
\hline 180 & $32.41 b$ & $32.45 b$ & $32.54 b$ & $32.51 \mathrm{~b}$ \\
\hline 225 & $33.32 \mathrm{c}$ & $33.28 \mathrm{c}$ & $33.77 \mathrm{~cd}$ & $33.96 \mathrm{~d}$ \\
\hline
\end{tabular}

Keterangan: Angka-angka yang diikuti oleh huruf yang sama pada kolom yang sama menunjukkan tidak berbeda nyata berdasarkan uji DMRT pada taraf $\alpha=5 \%$

Tabel 6. Bobot kering batang tebu $\left(\mathrm{g} \mathrm{m}^{-2}\right)$ pada tingkat pemupukan $\mathrm{N}$ saat fase anakan maksimum (3 BST), fase batang maksimum (9 BST) dan fase panen (11 BST)

\begin{tabular}{lccc}
\hline \multirow{2}{*}{ Dosis N $\left(\mathrm{kg} \mathrm{N} \mathrm{ha}^{-1}\right)$} & \multicolumn{3}{c}{ Bobot kering batang $\left(\mathrm{g} \mathrm{m}^{-2}\right)$} \\
\cline { 2 - 4 } & $3 \mathrm{BST}$ & $9 \mathrm{BST}$ & 11 BST \\
\hline 90 & $12.97 \mathrm{a}$ & $49.53 \mathrm{a}$ & $66.81 \mathrm{a}$ \\
135 & $13.53 \mathrm{~b}$ & $50.32 \mathrm{~b}$ & $68.46 \mathrm{~b}$ \\
180 & $14.05 \mathrm{c}$ & $52.19 \mathrm{c}$ & $70.88 \mathrm{c}$ \\
225 & $14.90 \mathrm{~d}$ & $53.13 \mathrm{~d}$ & $76.47 \mathrm{~d}$ \\
\hline
\end{tabular}

Keterangan: Angka-angka yang diikuti oleh huruf yang sama pada kolom yang sama menunjukkan tidak berbeda nyata berdasarkan uji DMRT pada taraf $\alpha=5 \%$ 
tetapi di sisi lain bila tanaman banyak mengandung $\mathrm{N}$ pada fase pemasakan akan menurunkan rendemen. Glaz et al. (2000) mengemukakan bahwa hasil millable cane (biomassa tebu yang dipanen) optimal yang dicapai pada aplikasi pemupukan $\mathrm{P}$ berkisar 100-200 kg P ha-1.

Bobot kering batang pada fase 3, 9 dan 11 BST, perlakuan $225 \mathrm{~kg} \mathrm{~N} \mathrm{ha-1} \mathrm{nyata} \mathrm{lebih} \mathrm{tinggi} \mathrm{dibanding}$ perlakuan lainnya (Gambar 5A, Tabel 6). Sebaliknya, bobot kering batang pada fase 3 BST, 9 BST dan 11 BST berdasarkan perlakuan $\mathrm{P}$ cenderung stagnan (tetap) dan relatif sama antar perlakuan dengan nilai tertinggi pada perlakuan $144 \mathrm{~kg} \mathrm{P} \mathrm{ha-1} \mathrm{(Gambar} \mathrm{5B,} \mathrm{Tabel} \mathrm{7).}$

Berdasarkan Gambar 6, hubungan antara efisiensi penggunaan cahaya matahari dan bobot kering batang tebu dengan koefisien determinasi $\mathrm{R}=0.8849$. Peningkatan efisiensi penggunaan cahaya matahari oleh tanaman tebu memicu peningkatan bobot kering batang tebu. Bobot kering batang tebu maksimal pada $53.59 \mathrm{~g} \mathrm{~m}^{-2}$ dengan nilai efisiensi penggunaan cahaya matahari sebesar $2.29 \mathrm{~g} \mathrm{MJ}^{-1}$.

Tabel 7. Bobot kering batang tebu $\left(\mathrm{g} \mathrm{m}^{-2}\right)$ pada tingkat pemupukan $\mathrm{P}$ saat fase anakan maksimum (3 BST), fase batang maksimum (9 BST) dan fase panen (11 BST)

\begin{tabular}{lccl}
\hline \multirow{2}{*}{ Dosis $\mathrm{P}\left(\mathrm{kg} \mathrm{P} \mathrm{ha}^{-1}\right)$} & \multicolumn{3}{c}{ Bobot kering batang $\left(\mathrm{g} \mathrm{m}^{-2}\right)$} \\
\cline { 2 - 4 } & $3 \mathrm{BST}$ & $9 \mathrm{BST}$ & $11 \mathrm{BST}$ \\
\hline 36 & $13.53 \mathrm{a}$ & $50.90 \mathrm{a}$ & $69.69 \mathrm{a}$ \\
72 & $13.71 \mathrm{a}$ & $51.01 \mathrm{ab}$ & $70.26 \mathrm{ab}$ \\
108 & $14.02 \mathrm{~b}$ & $51.54 \mathrm{bc}$ & $70.82 \mathrm{bc}$ \\
144 & $14.19 \mathrm{~b}$ & $51.73 \mathrm{c}$ & $71.86 \mathrm{c}$ \\
\hline
\end{tabular}

Keterangan: Angka-angka yang diikuti oleh huruf yang sama pada kolom yang sama menunjukkan tidak berbeda nyata berdasarkan uji DMRT pada taraf $\alpha=5 \%$
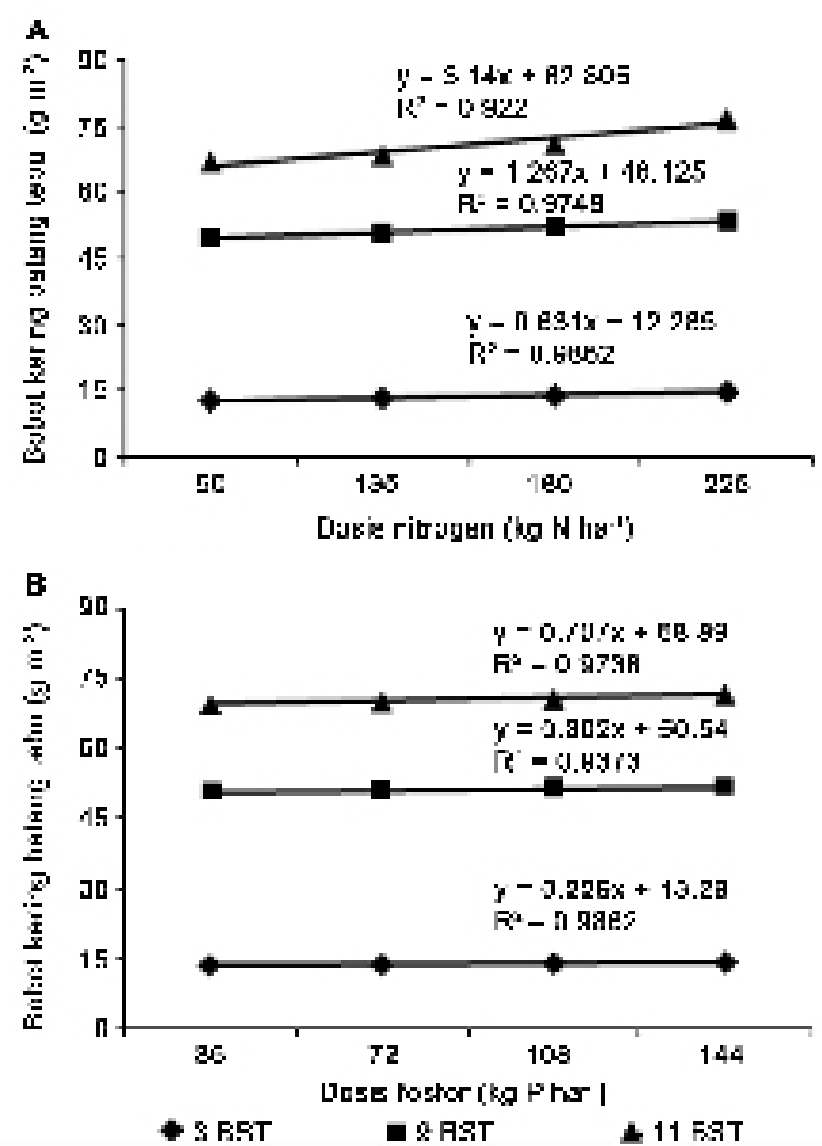

Gambar 5. Bobot kering batang tebu pada tingkat pemupukan $N$ (A) dan P (B) pada saat fase anakan maksimum (3 BST), fase batang maksimum (9 BST) dan fase panen (11 BST)

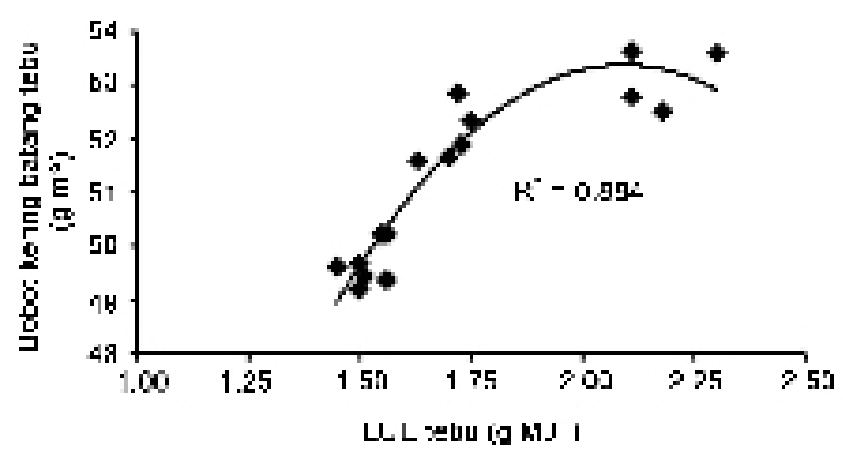

Gambar 6. Hubungan efisiensi penggunaan cahaya matahari oleh tanaman tebu dan berat kering batang tebu

\section{KESIMPULAN}

Peningkatan pemupukan nitrogen $(\mathrm{N})$ meningkatkan nilai efisiensi penggunaan cahaya matahari oleh tanaman tebu. Pemupukan $225 \mathrm{~kg} \mathrm{~N}^{-1}$ menghasilkan nilai efisiensi penggunaan cahaya matahari oleh tanaman tebu pada fase batang maksimum yaitu $2.29 \mathrm{~g} \mathrm{MJ}^{-1}$. Peningkatan nilai efisiensi penggunaan cahaya matahari ini juga terlihat pada peningkatan bobot kering batang tebu yang merupakan komponen utama produksi tebu. Peningkatan pemupukan $P$ tidak meningkatkan nilai efisiensi penggunaan cahaya tanaman tebu namun demikian berpengaruh pada bobot kering batang tebu fase anakan maksimum, fase batang maksimum dan fase panen (11 BST); bobot kering total tebu fase anakan tetap dan fase batang maksimum. Interaksi pemupukan $\mathrm{N}$ dan $\mathrm{P}$ tidak meningkatkan nilai efisiensi 
penggunaan cahaya tanaman tebu, kecuali pada bobot kering batang tebu fase muncul lapang dan fase anakan tetap, bobot kering total tebu fase muncul lapang.

\section{DAFTAR PUSTAKA}

Allison, J.C.S., N.W. Pammentor. 2002. Effect of nitrogen supply on the production and distribution of dry matter in sugarcane. J. Plant Soil 19:12-16.

Awal, A.M., H. Koshi, T. Ikeda. 2006. Radiation interception and use by maize/peanut intercrop canopy. Agr. Forest Meteorol. 139:74-83.

Caviglia, O.P., V. Sadras. 2001. Effect of nitrogen supply on crop conductance, water and radiation use efficiency of wheat. Field Crop. Res. 69:259-266.

Fletcher, L.A., D.J. Moot., P.J. Stons. 2008. Radiation use efficiency and leaf photosynthesis of sweet corn in response to phosphorus in a cool temperate environment. Eur. J. Agron. 29:88-93.

Glaz, B., G. Powell., R. Perdomo, M.F. Ulloa. 2000. Sugarcane response to phosphorus fertilizer in relation to soil test recommendations on everglades histosols. Agron. J. 92:375-380.

Inman-Bamber, N.G. 1994. Temperature and seasonal effects on canopy development and light interception of sugarcane. Field Crop. Res. 36:41-51.

Lecoeur J., B. Ney. 2003. Change with time in potential radiation-use efficiency in field pea. Eur. J. Agron. 19:91-105.

Martine, J.F., P. Siband., R. Bonhomme. 1999. Simualtion of the maximum yield of sugarcane at different altitudes: effect of temperature on the conversion of radiation into biomass. J. Agronomic 19:3-12.
Muchow, R.C., M.F. Spillman., A.W. Wood., M.R. Thomas. 1994. Radiation interception and biomass accumulation in a sugarcane crop grown under irrigated tropical conditions. Aust. J. Agr. Res. 45:37-49.

Muchow, R.C., C.I. Evensen., R.V. Ongood., M.J. Robertson. 1997. Yield accumulation in irrigated sugarcane : II. utilization of intercepted radiation. Agron. J. 89:646652 .

Prabawa, S. 2006. Pendekatan Precision Farming dalam Pemupukan NPK pada Budidaya Tebu (Studi Kasus di PT Gula Putih Mataram). Disertasi. Sekolah Pasca Sarjana. Institut Pertanian Bogor. Bogor.

Salgado, G.S., R.N. Escobar., J.J. Pena. 2002. Response of sugarcane ratoon to NPK fertilization. Agrociencia J. 34:689-698.

Salvagiotti, F., D.J. Miralles. 2008. Radiation interception, biomass production and grain yield as affected by the interaction of nitrogen and sulfur fertilization in wheat. Eur. J. Agron. 28:282-290.

Singh, N.P., S.C. Mohan. 1994. Water use and yield response of sugarcane under different irrigation schedules and nitrogen levels in a subtropical region. Agr. Water Manage. 26:253-264.

Sundara, B. 1998. Sugarcane Cultivation. First Edition. Vikas Publishing House Pvt Ltd, New Delhi.

Susila, A.D., J.G. Kartika., T. Prasetyo., M.C. Palada. 2010. Fertilizer recommendation: correlation and calibration study of soil $\mathrm{P}$ test for yard long bean (Vigna unguilata L.) on ultisols in Nanggung - Bogor. J. Agron. Indonesia 38 :225-231.

Wiedenfeld, B., J. Enciso. 2008. Sugarcane responses to irrigation and nitrogen in semiarid South Texas. Agron J. 100:665-671. 